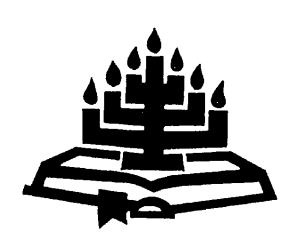

\title{
'n Teologies-etiese beoordeling van kinderarbeid in Suid-Afrika
}

\author{
E.J. de Beer \\ Skool vir Kerkwetenskappe \\ Potchefstroomkampus \\ Noordwes-Universiteit \\ POTCHEFSTROOM \\ E-pos: edmunddebeer@lantic.net
}

\section{Abstract \\ A theological-ethical judgement of child labour in South Africa}

Throughout the world child labour is a problem which has been under especially close scrutiny for the past three decades. Although child labour is not such a serious problem in South Africa as is the case in some other countries, unacceptable forms of child labour also occur here. Socio-economic circumstances force most child labourers to work in order to survive. The result is that these children are deprived of a good education and training in order to occupy positions as adults in order to earn a living wage.

In this article child labour is judged as it occurs in South Africa. Child labour is judged in the light of theological-ethical utterances on children as well as on labour. Although the demand to labour is universal (and thus also applies to children), it is obvious that they cannot labour in the same way as adults. Children should rather be educated and equipped to develop their abilities in order to utilise it to the maximum as adult workers.

\section{Opsomming}

'n Teologies-etiese beoordeling van kinderarbeid in Suid-Afrika

Kinderarbeid is wêreldwyd 'n probleem wat die afgelope drie dekades opnuut onder die soeklig gekom het. Alhoewel kinderarbeid in Suid-Afrika nie so 'n ernstige probleem is soos in sommige ander lande nie, vind hier ook onaanvaarbare vorms van kinderarbeid plaas. Die meeste kinderarbeiders word vanweë 
hulle sosio-ekonomiese omstandighede gedwing om ter wille van oorlewing te werk. Hulle word die geleentheid ontneem om goed opgevoed en opgelei te word sodat hulle as goedtoegeruste volwassenes werk kan verrig waarvoor hulle na behore vergoed sal word.

In hierdie artikel word kinderarbeid soos dit in Suid-Afrika voorkom, beoordeel. Die beoordeling vind plaas in die lig van 'n aantal teologies-etiese uitgangspunte oor kinders en arbeid. Hoewel die arbeidsopdrag universeel is (dus ook vir kinders geld), is dit logies dat kinders nie dieselfde arbeid as volwassenes kan verrig nie. Kinders behoort eerder opgevoed en toegerus te word om hulle vermoëns sodanig te ontwikkel, dat hulle as volwasse werkers hulle vermoëns ten volle kan benut.

\section{Inleiding}

Daar is ongeveer 217 miljoen kinderwerkers in die wêreld. Ongeveer 126 miljoen van hierdie kinders verrig gevaarlike werk (Hagemann et al., 2006:2).

Kinderarbeid het aan die begin van die twintigste eeu baie aandag op internasionale vlak geniet. In 1924 het die Volkebond die Verklaring van Regte van Kinders aanvaar. Daarna is dekades lank min aandag aan kinderarbeid gewy. Globalisering en 'n groter bewuswording van die ekonomiese uitbuiting van miljoene kinders dwarsoor die wêreld het regerings, internasionale organisasies en die sakesektor genoop om gedurende die tagtiger- en negentigerjare van die vorige eeu meer aandag aan hierdie probleem te skenk (Fyfe, 2007:21; Weissbrodt \& Anti-Slavery International, 2002:37).

Ook in Suid-Afrika is daar duisende kinderarbeiders. Ongeveer 400000 kinders in Suid-Afrika tussen die ouderdomme van 5 en 17 jaar is weekliks twaalf uur of langer met ekonomiese aktiwiteite besig (South Africa. DL, 2003:13).

Hoewel werk op sigself nie noodwendig kinders benadeel nie, kan dit kinders wel fisies, verstandelik, psigies of sedelik tot nadeel strek. Ten spyte van die nadelige uitwerking wat kinderarbeid soms het, word die meeste kinderarbeiders gedwing om te werk ter wille van hulle eie en hulle families se ekonomiese oorlewing.

In hierdie artikel word ondersoek ingestel na kinderarbeid soos dit in Suid-Afrika voorkom. Die doel van die ondersoek is om vanuit 'n Christelike perspektief kinderarbeid in Suid-Afrika te beoordeel. 


\section{Definiëring van kinderarbeid}

By die beoordeling van kinderarbeid is dit noodsaaklik om eers vas te stel tot op watter ouderdom 'n persoon as 'n kind gereken word, en ook watter werksaamhede as kinderarbeid beskou word. In hierdie opsig gee internasionale konvensies belangrike riglyne. Die Internasionale Arbeidsorganisasie se Minimum Ouderdom Konvensie (ILO, 1973) bepaal dat geen persoon onder die minimum skoolpligtige ouderdom mag werk nie, op voorwaarde dat die minimum ouderdom nie laer as vyftien is nie. Dieselfde konvensie bepaal ook dat geen persoon jonger as agtien jaar oud werk mag verrig wat sy/haar gesondheid, veiligheid of sedes benadeel nie. Die Ergste Vorms van Kinderarbeid Konvensie (ILO, 1999) van die Internasionale Arbeidsorganisasie definieer ' $n$ kind as ' $n$ persoon onder die ouderdom van agtien jaar. Die Verenigde Nasies se Konvensie oor Kinderregte en die Organisasie van Afrika Eenheid se Handves oor die Regte en Welsyn van die Kind beskou 'n kind ook as iemand onder die ouderdom van agtien jaar (UN, 1989; OAU, 1990).

In Suid-Afrika verbied die Wet op Basiese Diensvoorwaardes (South Africa, 1997) dat 'n kind jonger as vyftien jaar in diens geneem mag word. Hoewel hierdie wet nie bepaal tot op watter ouderdom 'n persoon as 'n kind gereken word nie, definieer die Kinderwet (South Africa, 2005) 'n kind as 'n persoon onder die ouderdom van agtien jaar. Die Suid-Afrikaanse Grondwet (South Africa, 1996a) bepaal dat ' $n$ kind onder agtien die reg het om beskerm te word teen uitbuiting op die arbeidsterrein, werk wat nie vir 'n kind van daardie ouderdom geskik is nie, of werk wat 'n kind se welstand, opvoeding, fisiese of geestelike gesondheid, of geestelike, morele of sosiale ontwikkeling in gevaar stel.

In die lig van bogenoemde word 'n kind in hierdie artikel gereken as 'n persoon onder die ouderdom van agtien jaar.

Wat word as kinderarbeid beskou? Die Kinderwet (South Africa, 2005) definieer kinderarbeid as werk wat kinders onder die ouderdom van agtien doen wat uitbuitend, gevaarlik of onvanpas is vir hulle ouderdom, of tot nadeel van hulle skoolonderrig, of sosiale, fisiese, geestelike of sedelike ontwikkeling is. Volgens hierdie definisie is kinderarbeid meer as bloot arbeid wat daarop gerig is om ' $n$ inkomste te verdien. Kinderarbeid sluit ook take of huishoudelike aktiwiteite in wat binne die raamwerk van bogenoemde definisie pas (Orkin, 2000:11). Genoemde definisie word as breë raamwerk gebruik vir kinderarbeid, terwyl in hierdie artikel hoofsaaklik gekonsentreer word op werk wat Suid-Afrikaanse kinders onder die ouderdom 
van agtien verrig met die oog daarop om 'n direkte inkomste te verdien, of werk wat sonder direkte vergoeding gedoen word met die oog op die ekonomiese oorlewing van die kind en sy familie. 'n Voorbeeld van laasgenoemde is 'n kind uit 'n arm huishouding wat daagliks ure bestee om brandhout op te tel of water aan te dra. So 'n kind word nie geldelik vir sy arbeid vergoed nie, maar sy werk is noodsaaklik vir sy familie se ekonomiese oorlewing.

Kinderarbeid sluit dus nie aktiwiteite in wat verband hou met skoolonderrig, kultuur- en sportbeoefening of normale pligte in die huishouding nie.

\section{Voorkoms en omvang van kinderarbeid}

Die meeste kinderarbeiders kom in Asië en die Stille Oseaangebiede (122 miljoen) en Afrika, Suid van die Saharawoestyn (49 miljoen) voor (Hagemann et al., 2006:2).

In 1999 het Statistiek Suid-Afrika die eerste huishouding-gebaseerde peiling oor kinderarbeid in Suid-Afrika gedoen, naamlik die Survey of Activities of Young People (SAYP). Uit die peiling en ander navorsing blyk dat kinderarbeid in Suid-Afrika nie so 'n ernstige probleem soos in sommige ander lande is nie. Die omvang van kinderarbeid in die formele sektore van die ekonomie is beperk. Alhoewel kinderarbeid in Suid-Afrika nie so omvangryk is soos in sommige ander lande nie, is daar wel 'n beduidende aantal kinders wat onaanvaarbaar baie werk doen, of werk van onaanvaarbare aard doen (South Africa. DL, 2003:2).

Die nasionale peiling van 1999 het bevind dat 45\% van die 13,4 miljoen kinders van vyf- tot sewentienjarige ouderdom by een of ander werkverwante aktiwiteit betrokke was. Die peiling het ook aangedui dat $49 \%$ van die Afrikaankinders, $22 \%$ van die bruin kinders, $10 \%$ van die Indiërkinders en $9 \%$ van die wit kinders in Suid-Afrika kinderarbeid verrig (Orkin, 2000:20).

Hierdie kinders het gemiddeld een of meer ure per week aan 'n ekonomiese aktiwiteit, vyf of meer ure per week aan skoolwerk en sewe of meer ure per week aan huishoudelike take bestee. Ongeveer 1,1 miljoen kinders ( $8 \%$ van die land se kinders van vyf tot sewentien jaar) het drie of meer ure aan ekonomiese aktiwiteite gewy. Dit sluit onbetaalde huishoudelike take en die insameling van hout of water uit (Orkin, 2000:19, 20, 22). 
Die versameling van hout en die aandra van water is van die belangrikste ekonomiese aktiwiteite waarmee kinders hulle besig hou. Van die kinders wat drie of meer ure per week aan ekonomiese aktiwiteite bestee, het $26 \%$ meisies en $21 \%$ seuns die tyd gebruik om hout op te tel en water aan te dra. Ongeveer 1,2 miljoen kinders het minstens agt ure per week aan hierdie aktiwiteite spandeer (Orkin, 2000:24, 25). Ander navorsing dui daarop dat meer as 250000 kinders in 2000 meer as 22 uur per week gebruik het om brandstof (hout) te versamel (South Africa. DL, 2003:49).

Kinders in verafgeleë landelike gebiede was die waarskynlikste om drie of meer ure per week ekonomies aktief te wees, gevolg deur kinders in kommersiële landbougebiede (11\%). In stedelike informele gebiede het $6 \%$ en in stedelike formele gebiede $5 \%$ van die kinders gewerk (South Africa. DL, 2003:13).

Ongeveer 117000 kinders (8\% van kinderwerkers) was in die kommersiële landbou werksaam. Die helfte van hierdie kinders het onbetaalde werk op familiegrond gedoen. Die ander helfte is deur iemand anders in diens geneem (South Africa. DL, 2003:55). Minstens 48\% (550 000) van die ekonomies aktiewe kinders (onbetaalde huishoudelike werk en water- en houtinsameling uitgesluit) wat drie uur of langer arbeid per week verrig het, was werksaam in bestaansboerderye of op familieplasies (South Africa. DL, 2003:58).

Volgens die SAYP het die tweede meeste hoeveelheid kinders in die kleinhandel en verwante sektore gewerk. Onder kleinhandel is werk in die akkommodasiebedryf, die herstel van motorvoertuie, die was en oppas van motors en dienste in die taxibedryf ingesluit. Ongeveer $45 \%$ van die dogters en ongeveer $27 \%$ van seuns wat gewerk het, was in die kleinhandel en verwante sektore werksaam. Die helfte van die kinders het sonder vergoeding in familiebesighede soos spaza-winkels gewerk, 'n derde het vir hulleself gewerk en die res vir iemand anders (South Africa. DL, 2003:59).

Een uit 'n duisend kinders het drie of meer ure per week daaraan bestee om kos of geld te bedel. Meer as die helfte van hulle (57\%) het twaalf of meer ure per week gebedel (South Africa. DL, 2003: 62).

Dit is moeilik om te bepaal hoeveel kinders in bedrywe soos prostitusie, pornografie en dwelmhandel werksaam is, maar dit kan 'n aansienlike getal wees, aangesien berekenings daarop dui dat daar tot soveel as 28000 kinderprostitute in die land is (Bhengu, 2001:1). 
Die Wet op Basiese Diensvoorwaardes (South Africa, 1997) laat toe dat kinders wel onder sekere voorwaardes werksaam mag wees in die advertensiewese, of met sport, artistieke of kulturele aktiwiteite. Die Internasionale Arbeidsorganisasie se Minimum Ouderdom Konvensie (ILO, 1973) maak ook voorsiening vir sulke uitsonderings. Daar is geen betroubare statistiek beskikbaar oor die hoeveelheid kinders wat sulke wettige werk verrig nie. Dit is waarskynlik 'n klein getal (South Africa. DL, 2003:62).

\section{Vergoeding van kinderwerkers}

Soos reeds aangedui, is daar duisende kinders wat sonder vergoeding lang ure elke week aan verskillende take bestee ter wille van hulle huishoudings se ekonomiese oorlewing. Daar is egter ook duisende kinderwerkers wat wel vir hulle arbeid vergoed word. Daar is nie betroubare inligting beskikbaar oor die vergoeding wat hulle ontvang nie. Uit die beskikbare bronne blyk dit egter dat hierdie kinderwerkers 'n klein vergoeding vir hulle arbeid ontvang. Dit gebeur ook dat kinders nie met geld vergoed word nie, maar met klere en kos. Laasgenoemde gebeur veral waar ouers hulle kinders aan bure, vriende en familie "uitverhuur" vir seksuele misbruik (Anon., 1997: 44; Bhengu, 2000a:1).

\section{Oorsake van kinderarbeid}

Die grootskaalse werkloosheid in Suid-Afrika het onder meer tot gevolg dat lone na onder gedruk word. Lae lone, tesame met die groot getal mense wat van elke werker afhanklik is, veroorsaak dat alle lede in families gedwing word om een of ander vorm van werk te verrig om inkomste te verdien. Ook kinders word hierdeur geraak. Armoede dwing ouers en voogde om werk vir hulle kinders te soek, ten einde die familie se nood te help verlig. Armoede is so omvangryk dat $59 \%$ van die kinders wat in Suid-Afrika werk, voel dat dit hulle plig is om hulle families te help, 'n verdere $15 \%$ werk om hulle families finansieel te help terwyl slegs $16 \%$ werk om ekstra sakgeld te verdien (South Africa. DL, 2003:13). Soms werk kinders sonder vergoeding in hulle huise om hulle ouers in staat te stel om te werk en 'n inkomste te verdien (Galli, 2001:2).

Van die kinders wat van bedelary afhanklik is, woon $61 \%$ nie by hulle ouers nie en is op hulleself aangewese om te oorleef (South Africa. DL, 2003:14).

In die afgelope aantal jare het die MIV- en VIGS-pandemie baie kinders wees gelaat. Hierdie kinders word gedwing om ter wille van 
oorlewing te werk (Anon., 2000a:1). Uit die 2001-sensus blyk dat daar in 2001 reeds 248000 huishoudings was wat deur kinders gelei is. Hierdie getal het sedertdien aansienlik toegeneem (Skweyiya, 2007). Alles dui daarop dat al hoe meer kinders in die toekoms gedwing sal word om te werk. Navorsingsvooruitskatting dui daarop dat die aantal kinders wat een of albei ouers weens MIV- en VIGS sal verloor, in 2014-2015 'n hoogtepunt kan bereik. Teen daardie tyd kan dit wees dat 5,7 miljoen kinders een of albei ouers aan die dood afgestaan het (South Africa. DL, 2003:75).

Internasionale navorsing dui daarop dat weeskinders in die ontwikkelende wêreld minder as $2 \%$ van die bevolking uitmaak en hulle word in daardie geval gewoonlik in uitgebreide families en die gemeenskap opgeneem. Daar word verwag dat die getal weeskinders in Suid-Afrika sodanig sal styg dat hulle teen 2015 waarskynlik 9$12 \%$ van die kinderbevolking sal uitmaak (South Africa. DL, 2003: 75). Hiervan gaan 'n groot aantal kinders nie deur die uitgebreide familie opgeneem kan word nie. Hierdie kinders sal op hulleself aangewese moet wees om te oorleef.

Selfs voordat geïnfekteerde ouers sterf, kan hulle kinders in ekonomiese terme weeskinders wees, aangesien die kinders na hulle siek ouers se behoeftes asook na hulle eie behoeftes moet omsien (South Africa. DL, 2003:75). Dit het tot gevolg dat nóg meer kinders die skool voortydig sal verlaat om werk te soek in 'n poging om te oorleef.

\section{Gevolge van kinderarbeid}

'n Positiewe gevolg van kinderarbeid is dat dit op die korttermyn help dat hulle families ekonomies oorleef (Galli, 2001:2). Die negatiewe gevolge oorskadu egter die positiewe gevolge.

Kinderarbeid het omvangryke negatiewe gevolge vir kinders self. Dit ontneem kinders die geleentheid om kind te wees en behoorlike skoolonderrig te ontvang. Baie kinderwerkers woon skool ongereeld by, of staak hulle onderrig vroeg (vgl. Dachi \& Garret, 2003:12). Sulke kinders ontwikkel nie hulle vermoëns na behore nie, gevolglik is hulle vermoë om as volwassenes goed-betaalde beroepe te beklee ook nie ontwikkel nie. Waar kinderarbeid op groot skaal voorkom, word armoede van geslag tot geslag oorgedra (Galli, 2001:3). Armoede is 'n struikelblok vir kinders om 'n behoorlike lewenstandaard te handhaaf en opvoeding, kennis en noodsaaklike lewensvaardighede op te doen en te ontwikkel. Kinders wat hiersonder grootword, is besonder blootgestel aan mishandeling en uitbuiting (UNICEF, 
2005:12). Omvangryke kinderarbeid belemmer die langtermyn ekonomiese groei in 'n land (Galli, 2001:7).

Waar kinders lang ure aan werk bestee, is hulle arbeid op ekonomiese oorlewing gerig. Van Dijk (1985:28, 143-144) wys daarop dat daar verskillende soorte arbeid bestaan. Benewens werk wat verrig word om te oorleef, is daar ook kommunikatiewe arbeid (die totstandkoming van verhoudings tussen mense) en nadenkende arbeid waarmee na waarheid en sin gesoek word. Kinderarbeiders word die geleentheid ontneem om na behore in laasgenoemde tipe werke ingelei en blootgestel te word.

Radebe (2001:4) wys daarop dat daar in die wêreld miljoene volwassenes is wat werkloos is of wat baie laag besoldig word. Daar is ook miljoene kinders wat werk en sodoende word die werksgeleenthede vir volwassenes verminder. Kinders is oor die algemeen bereid om vir kleiner inkomstes te werk. Kinderarbeid veroorsaak dat die bestaande ooraanbod van laagbesoldigde werkers verder vergroot, en hulle lone afwaarts gedwing word (vgl. Galli, 2001:17).

Baie kinderarbeiders is nie slegs ongeletterd nie, maar dra ook sielkundige letsels (Bhengu, 2000b:11). Baie kinders wat werk, word ook fisies benadeel. 'n Ondersoek het aangetoon dat $2 \%$ van die kinders wat in Suid-Afrika werk, sê dat hulle as gevolg van hulle werk siek geword het, terwyl 'n verdere $4 \%$ beweer dat hulle by die werk beseer is (Anon., 2000b:13).

\section{Optrede om kinderarbeid te bekamp}

Tot in 1997 het die Wet op Kindersorg werkgewers verbied om kinders onder die ouderdom van vyftien jaar in diens te neem of aan hulle werk te verskaf (Labuschagne, 1994:348). Sedertdien het die Suid-Afrikaanse regering reeds verskeie stappe gedoen om kinderarbeid te probeer uitroei. Die minister van arbeid wys daarop dat die regering in sy stryd teen kinderarbeid reeds verskeie internasionale konvensies wat verband hou met kinderarbeid geratifiseer het (Mdladlana, 2002). Die konvensies wat reeds geratifiseer is, is die volgende:

- Die Verenigde Nasies Konvensie oor Kinderregte (United Nations, 1989);

- die Minimum Ouderdom Konvensie (ILO, 1973) en die Ergste Vorms van Kinderarbeid Konvensie (ILO, 1999) van die Internasionale Arbeidsorganisasie; sowel as 
- die Organisasie van Afrika Eenheid se Handves oor die Regte en Welsyn van Kinders (OAU, 1990).

Verskeie wette wat verband hou met kinderarbeid is in ooreenstemming met hierdie konvensies opgestel. Bepalings met betrekking tot kinderarbeid word gevind in die Suid-Afrikaanse Skolewet (South Africa, 1996b), die Wet op Basiese Diensvoorwaardes (South Africa, 1997b) en die Kinderwet (South Africa, 2005). Die Suid-Afrikaanse Skolewet stel dit duidelik dat kinders skoolpligtig is tot die minimum ouderdom van vyftien jaar. Die Wet op Basiese Diensvoorwaardes bepaal dat die minimum ouderdom waarop ' $n$ kind in diens geneem mag word, nie laer as die minimum skoolverlatingsouderdom mag wees nie, maar dat dit in elk geval nie jonger as vyftien sal wees nie. Deur die minimum ouderdom aan die skoolverlatingsouderdom te koppel, word gepoog om te keer dat werk met kinders se ontwikkeling inmeng en om jongmense in staat te stel om so goed as moontlik toegerus te word om die volwasse arbeidsmark te kan betree (ILO, 2002:7). Hierdie wet verbied werkgewers wat kinders (vyftien jaar en ouer) in diens neem, om hulle werk te laat doen wat nie by hulle ouderdom pas nie, of wat hulle welstand, opvoeding, fisiese en geestelike gesondheid of geestelike, morele en sosiale ontwikkeling benadeel.

Die Kinderwet (South Africa, 2005) verbied uitdruklik dat 'n kind onder die ouderdom van 15 jaar in diens geneem mag word of dat 'n kind aangemoedig of verplig mag word om werk te doen wat tot nadeel van sy/haar gesondheid of moraal is. Werk wat 'n kind se welsyn, opvoeding, fisiese of geestelike gesondheid, geestelike, morele of sosiale ontwikkeling in gevaar stel, word ook buite perke gestel.

'n Program is ook deur die regering ontwikkel om 'n einde aan kinderarbeid te maak. Die program is aanvanklik die Child Labour Action Programme (CLAP) genoem, maar is in 2006 verander na die Child Labour Programme of Action. In hierdie program is ' $n$ wye reeks aktiwiteite geïdentifiseer wat binne die mandate van ' $n$ wye verskeidenheid staatsdepartemente val. Kragtens die program werk die departemente saam om kinderarbeid te verminder (South Africa. DL, 2003:3). Die program het ten doel om toe te sien dat die regering en ander belanghebbendes se programme en beleide rakende armoede, werkverskaffing, arbeid en sosiale sake nie tot nadeel van kinders is nie. Die program beywer hom vir nuwe wetgewing teen die ergste vorms van kinderarbeid. Dit wil ook wetstoepassing bevorder en die publiek bewus maak van die ergste vorms van kinderarbeid (South Africa. DL, 2003:4). 
Die betaling van verskillende toelaes (bv. kindertoelae en pleegsorgtoelae) en hulp aan kindergeleide huishoudings is deel van die regering se pogings om kinders minder weerloos te maak (South Africa. DL, 2003:19; Skweyiya, 2007). Die gratis verskaffing van minimum hoeveelhede water en elektrisiteit aan elke huishouding stel kinders in staat om meer tyd aan skoolwerk te bestee, omdat duisende kinders minder tyd hoef te verwyl om water aan te dra of brandhout te versamel (South Africa. DL, 2003:51). Die instelling van minimum lone vir huiswerkers in 2002 behoort 'n demperende effek op kinderarbeid in hierdie sektor te hê, omdat alle huiswerkers, ongeag hulle ouderdom, op dieselfde minimumloon geregtig is (vgl. South Africa. DL, 2003:53). Met die Kinderwet (South Africa, 2005) word gepoog om weerlose kinders te beskerm deur hulle onder meer in staat te stel om in hulle gemeenskappe te bly (Skweyiya, 2007).

Die eerste vervolging in terme van die Wet op Basiese Diensvoorwaardes (South Africa, 1997b) het in 2002 plaasgevind toe die eienaars van 'n plaas met R25 000 beboet is, omdat kinders onder die ouderdom van vyftien jaar in diens geneem is om vrugte te pluk en op te tel (Prince \& Arends, 2002:2). Nog 'n boer is in 2003 met R12 000 beboet, omdat hy twee dogters onder die ouderdom van vyftien in diens geneem het (Mabasa, 2003:4). Die Wet op Basiese Diensvoorwaardes word egter nie streng toegepas nie, omdat dit volgens 'n amptenaar van die departement van arbeid in die huidige omstandighede tot verdere nadeel van die betrokke kinders se welstand en lewensgehalte kan wees. Volgens hom word tans daarop gekonsentreer om die omstandighede wat die oorsaak is dat kinders moet werk, te verbeter. Daarna sal toegesien word dat kinders ophou werk (Bhengu, 2000c:13).

Armoedeverligting is ' $n$ belangrike stap in die vermindering van kinderarbeid (UNICEF, 2005:12). Die Suid-Afrikaanse regering probeer om deur middel van verskeie programme kinders se omstandighede direk of indirek te verbeter. Baie van die programme is op armoedeverligting gerig, byvoorbeeld openbare werksprogramme, voorsiening van die basiese infrastruktuur, toegang tot basiese dienste en die verskaffing van maatskaplike toelae waarby kinders baat kan vind (South Africa. DL, 2003:2).

\section{Teologies-etiese uitgangspunte}

By die beoordeling van kinderarbeid is daar verskillende teologiesetiese uitgangspunte wat in ag geneem moet word. Die uitgangspunte wat in berekening gebring behoort te word, word vervolgens uitgewerk. 


\subsection{Skepping van die mens}

Alle mense, ook kinders, is na God se beeld geskep (Gen. 1:26-28). Kinders is die mees weerlose draers van God se beeld. Hulle moet met waardigheid behandel word en hulle het die reg op beskerming (Smith, 1995:225). Dit sluit beskerming op die arbeidsterrein in.

Die belangrikheid om kinders menswaardig te behandel, word onder andere beklemtoon deur Jesus Christus se optrede teenoor kinders. Jesus se uitspraak dat elkeen wat 'n kind in sy Naam ontvang, Hom ontvang (Mark. 9:36-37), toon hoe kosbaar (waardig) enige persoon is, maar in besonder kinders. Die waarde van kinders en hulle menswaardige behandeling is nie 'n uitvindsel van die welsynstaat nie, maar is reeds in die skepping vasgelê. Jesus se optrede teenoor kinders is in ooreenstemming hiermee (Wessel, 1984:706).

\subsection{Arbeid as universele opdrag}

God het reeds voor die mens se skepping besluit dat arbeid deel van die mens se bestaan sal wees (Gen. 1:26). Daarom het Hy ná die mens se skepping aan hom opdrag gegee om onder meer die aarde te bewoon en te bewerk (Gen. 1:28; 2:15). Dit is 'n universele opdrag wat in beginsel vir alle mense, ook vir kinders, geld. Tog kan alle mense nie werk nie. Klein kindertjies, siekes en bejaardes val in hierdie groep (Norval, 1966:130). Namate klein kindertjies ouer word, ontwikkel hulle fisiese, verstandelike en geestelike vermoëns en is hulle al hoe meer in staat om die arbeidsopdrag te gehoorsaam. Gehoorsaamheid aan die arbeidsopdrag is nie iets wat meteens vanself gebeur nie. Dit gaan gepaard met die aanleer en ontwikkeling van vaardighede oor hoe om te werk.

\subsection{Kinders en arbeid in die Ou Testament}

Volgens Klaagliedere 3:27 is dit "goed vir 'n mens om sy las in sy jeug te dra". Die Ou-Testamentiese Jode het hierdie vers so verklaar dat die las op onderrig, familieversorging en werk betrekking gehad het (Bienert, 1956:78). Dit was dus goed as 'n mens in sy jeug leer en ook werk. In die Joodse samelewing was dit 'n vader se plig om sy seun op te lei om 'n beroep te beoefen. Seuns is gewoonlik in dieselfde beroep opgelei as wat hulle vaders beoefen het (Edersheim, 1988:182, 185). In die Bybel is talle voorbeelde van seuns wat dieselfde beroep as hulle vaders beoefen het. Jakobus en Johannes was, soos hulle pa, vissers (Matt. 4:21). Hulle was juis saam met hulle pa besig om nette reg te maak toe Jesus hulle geroep het. Jesus het ook dieselfde beroep as sy pa gevolg - timmermanne 
(Matt. 13:55; Mark. 6:3). Indien 'n vader nie sy seun geleer het om 'n beroep te beoefen nie, het die Jode dit beskou asof hy geleer is om te steel (Auerbach, 1944:185). Die opleiding het van jongs af tuis plaasgevind, omdat daar in die pre-nywerheidsamelewing nie 'n onderskeid tussen werk- en woonplek was nie.

Arbeid is nie 'n straf nie. Dit is in die Ou-Testamentiese tyd as 'n seën vir volwassenes asook vir kinders gesien. Deur te werk het kinders arbeidsmetodes, handvaardighede en die gewoonte om te werk, aangeleer. Verder het dit hulle ook moreel beskerm teen ondeug en die vreugde van werk geleer (Bienert, 1956:80).

In die Bybel vind 'n mens enkele voorbeelde van jongmense wat vanaf 'n redelike vroeë ouderdom gewerk het. Josef het op sewentienjarige leeftyd saam met sy broers kleinvee opgepas (Gen. 37:2). Ook Dawid het as sestien- of sewentienjarige skape opgepas (1 Sam. 16:12; Goslinga, 1959:204).

Uit die voorbeelde van Josef en Dawid blyk dit egter dat hulle nie daaraan blootgestel was om presies dieselfde werk as hulle ouer broers te verrig nie. Toe Josef se broers by Sigem vee opgepas het, het hy tuis gebly en as boodskapper namens sy vader opgetree (Gen. 37:12,13). Sigem was ongeveer 80 kilometer vanaf Hebron (Walton, 2001:664). Dit kan moontlik die rede wees waarom die relatief jong Josef by hierdie geleentheid tuis gebly en nie saam met sy broers vee opgepas het nie.

Dawid het as die jongste tuis gebly toe sy broers aan die oorlog teen die Filistyne (1 Sam. 17) deelgeneem het. Alhoewel hy moontlik reeds 20 of 21 jaar oud was (Goslinga, 1959:204), is hy nie aan dieselfde gevare as sy ouer broers blootgestel nie. Josef en Dawid se ouderdomme het waarskynlik 'n rol gespeel in die feit dat hulle nie dieselfde arbeid as hulle ouer broers verrig het nie.

Kinders het op die laatste in hulle tienerjare begin werk. Hierdie arbeid is gewoonlik saam met hulle ouers of broers gedoen. Op hierdie wyse het hulle 'n bydrae gelewer in die onderhoud van hulle families, maar is hulle ook opgelei sodat hulle mettertyd selfstandig kon werk om in hulle eie behoeftes te voorsien. Dit is nie van jongmense verwag om dieselfde werk as ouer werkers te verrig nie. Die arbeid wat kinders verrig het, het nie hulle ouers se versorgingsplig opgehef nie (vgl. 2 Kor. 12:14). 


\subsection{Voorkoming van armoede}

God het ook wette gegee waarmee voorkom is dat ' $n$ familie in 'n armoede-siklus beland. Elf van die stamme het grond in Kanaän ontvang (Num. 32; Deut. 3:12-30; Jos. 13-19). Hierdie grond is toegewys na gelang van die grootte van die families (Koole, 1964:125). Die grond was groot genoeg sodat 'n gesin, dus ook die kinders, goed versorg is. Ook die Levitiese families is genoegsaam uit die grond wat hulle ontvang het, versorg (Num. 35:1-50) asook die tiendes wat die ander stamme uit hulle opbrengs gegee het (Num. 18:20-21; Deut. 26:12).

Die ideaal was dat elke Israeliet sy erfpand moes bewoon en vir homself daarop moes werk (Agrell, 1976:29). Selfs wanneer iemand vanweë omstandighede verarm geraak en gedwing is om sy grond te verlaat en vir iemand anders te gaan werk, het die Jubeljaarwetgewing so 'n persoon of familie in staat gestel om sy grond wat hy moes verkoop, weer terug te kry (Lev. 25:13). Die erfdeel wat God aan sy volk gegee het, mag nie permanent in die hande van iemand anders oorgegaan het nie (Lev. 25:23; Num. 36:9), maar moes elke 50 jaar aan die oorspronklike eienaars teruggee word. Hierdie reëling het Israeliete wat sedert die vorige Jubeljaar verarm geraak het, in staat gestel om uit 'n moontlike armoede-sirkel los te breek. Kinders het nie deel gebly van 'n armoede-kringloop nie.

\subsection{Beskermingsmaatreëls}

Ten spyte van die toekenning van grond aan elke familie asook ander maatreëls wat armoede moes teenwerk, het dit tog gebeur dat sommige mense verarm het. Nie almal was in staat om te alle tye in hulle eie behoeftes te voorsien nie. Dit het noodwendig die afhanklike kinders van sodanige volwassenes geraak.

God het in die Ou Testament besondere maatreëls ingestel om vreemdelinge, weeskinders en weduwees te beskerm. Hierdie maatreëls was daarop ingestel om dit vir weerlose mense moontlik te maak om 'n menswaardige bestaan te voer. Die hele samelewing is hierby betrek. Israeliete is verbied om hulle landerye heeltemal skoon te oes, of om die wenakkers te oes (Lev. 19:9-10; Deut. 24:19-21). Weerlose mense kon hiervan leef.

God het hierdie maatreëls ingestel, omdat Hy sy volk uit slawerny bevry het (Deut. 24:22). Hulle vryheid het dit moontlik gemaak om 'n menswaardige bestaan te voer. Om hierdie rede moes niemand onder die Israeliete swaarkry nie en moes hulle gehelp word om 'n 
menswaardige lewe te lei. In sulke omstandighede kon kinders beskermd grootword sonder om fisies of psigies weens armoede benadeel te word.

\subsection{Sondeval}

Die sondeval het ' $n$ universele uitwerking gehad op die uitvoering van die arbeidsopdrag (Johannes Paulus II, 1981). Dit het tot gevolg dat die mens met swaarkry 'n bestaan uit die aarde moet maak (Kaiser, 1991:150). Dit word vererger deurdat die mens op die arbeidsterrein 'n sondaar geword het (Norval, 1966:120). Dit is alleen met moeisame werk wat die mens 'n bestaan kan maak (Agrell, 1976:12; Bienert, 1956:59).

Die uitwerking van die sondeval op die arbeidsterrein word duidelik deur die voorkoms van kinderarbeid in Suid-Afrika geïllustreer. As gevolg van die omvangryke werkloosheid in Suid-Afrika, armoede en die MIV- en VIGS-pandemie word duisende kinders (jongmense jonger as agtien) gedwing om ter wille van oorlewing te werk en 'n inkomste te verdien. Hierdie jong werkers word swak vergoed. Hulle werk maak inbreuk op hulle skoolonderrig en is gewoonlik nie daarop gerig om hulle toe te rus om eendag self sinvolle werk te verrig nie. Kinderarbeid dra by tot die groot aantal werklose volwassenes, omdat kinders bereid is om teen laer vergoeding te werk.

\subsection{Kinders en verlossing}

Die Christendom het 'n hoë waardering vir die menswaardigheid van kinders (Vorster, 2007:209). Vorster (2007:216-219) wys op die besondere plek wat kinders inneem in die verbond wat God met sy volk sluit. Hulle het deel aan die verbondsbeloftes en verbondseëninge. Kinders is as 'n seën uit God se hand beskou en is daarom reeds van vóór hulle geboorte af met respek behandel. Klein kindertjies het ook in die Ou en Nuwe Testament die teken van God se verbond ontvang.

In die Grieks-Romeinse kultuur is kinders nie belangrik geag nie. Daarteenoor het Jesus Christus kinders aangeraak, geseën en aan hulle geleer dat die koninkryk van God vir mense soos hulle is. Hy stel aan sy dissipels dat hy wat homself soos 'n kindjie gering ag, die belangrikste in die koninkryk van die hemel is.

Kinders word, soos volwassenes, uit genade in Jesus Christus gered. Hulle word deur hulle geloof gered en ontvang geloof as gawe. Kinders ontvang ook die nuwe lewe op grond van Christus se ver- 
lossingswerk. Die verlossingsleer ag kinders nie minder belangrik of onvolkome lede van Christus se liggaam nie. Vanuit hierdie hoek gesien, behoort kinders menswaardig behandel en hoog geag te word (Vorster, 2007:219, 220).

\subsection{Kinders en die werk van die Heilige Gees}

As volle lede van Jesus Christus se liggaam het kinders ook deel aan die gawes van die Heilige Gees. Die Heilige Gees werk nie slegs geloof in mense (ook kinders) nie, maar die gelowiges (ook kinders) moet die vrug van die Heilige Gees vertoon. Dit is liefde, vreugde, vrede, geduld, vriendelikheid, goedhartigheid, getrouheid, nederigheid en selfbeheersing (Gal. 5:22). Teenoor die vrug van die Gees staan die werke van die sondige natuur, naamlik onsedelikheid, onreinheid, losbandigheid, afgodsdiens, towery, vyandskap, haat, naywer, woede, rusies, verdeeldheid, skeuring, afguns, dronkenskap, uitspattigheid en dergelike dinge (Gal. 5:19). Gelowiges (insluitende gelowige kinders) word gewaarsku om nie hieraan deel te hê nie. Die Tien Gebooie geld ook vir kinders (Vorster, 2007:221). Ouers en volwassenes dra die verantwoordelikheid om toe te sien dat kinders opgevoed word, die Tien Gebooie gehoorsaam en die vrug van die Gees vertoon.

\section{Beoordeling}

By die beoordeling van kinderarbeid in Suid-Afrika moet onderskeid getref word tussen kinders se normale aktiwiteite (skoolonderrig, kultuur- en sportbeoefening en normale huishoudelike pligte) en arbeid wat verrig word wat tot nadeel van kinders se skoolonderrig, sosiale, fisiese, geestelike of sedelike ontwikkeling is (kinderarbeid). In die lig van die teologies-etiese perspektiewe op kinderarbeid is dit duidelik dat kinderarbeid soos dit in Suid-Afrika voorkom, nie aan die teologies-etiese beginsels vir kinderarbeid voldoen nie. Kinders word soms genoodsaak om vanweë hulle sosio-ekonomiese omstandighede werk te verrig wat nie by kinders pas as weerlose beelddraers van God nie. Hierdie kinders voer nie op 'n sinvolle manier God se arbeidsopdrag uit nie. Die meeste kinderwerkers se arbeid ondermyn behoorlike skoolonderrig. Dit berei kinders gewoonlik ook nie voor om eendag as volwassenes werk te verrig waar hulle vermoëns ten volle benut kan word nie. Derhalwe sal hulle ook nie 'n goeie inkomste kan verdien nie. Die kringloop van armoede, kinderarbeid en swak skoolonderrig word dus voortgesit. Vanweë die aard van hulle posisie in die samelewing, is kinders besonder weerloos en hulle word dikwels uitgebuit. 
Die onderliggende oorsake van kinderarbeid (werkloosheid, armoede, MIV en VIGS) behoort verdere aandag te geniet. Indien hierdie probleme nie opgelos word nie, sal kinderarbeid bly voortbestaan. Daar is geen vinnige en eenvoudige oplossing vir hierdie probleme nie. Dit onthef die verskillende rolspelers egter nie van hulle verantwoordelikheid om kinderarbeid en die gevolge daarvan te probeer voorkom nie.

Daar is 'n duidelike verband tussen kinderarbeid en kinders se opvoeding. Waar meer geld aan primêre en laer sekondêre onderrig bestee word, werk minder kinders (Hagemann et al., 2006:40). In hierdie opsig speel die staat 'n besondere rol om kinders in staat te stel om goeie onderrig te ontvang. Ouers het ook ' $n$ verantwoordelikheid om ten spyte van armoede hulle kinders so ver as moontlik goeie skoolonderrig te laat geniet, sodat hulle die geleentheid kan hê om hulle vermoëns so goed as moontlik te ontwikkel met die oog op 'n betrekking in die arbeidsmark. Op kinders rus die verantwoordelikheid om die geleenthede wat hulle het om onderrig te ontvang, na die beste van hulle vermoëns te gebruik. Sodoende word hulle toegerus vir betrekkings waar hulle vermoëns aangewend kan word en hulle dienooreenkomstig vergoed kan word.

Die verskaffing van minimum gratis water en elektrisiteit behoort in die lig van die kinderarbeidsprobleem positief beoordeel te word. Dit behoort kinders te help om meer tyd aan skoolonderrig en huiswerk te bestee, eerder as om hout en water te versamel.

Die betaling van verskillende toelaes om kinders minder weerloos te maak, moet ook positief beskou word. 'n Saak wat ernstige aandag behoort te geniet, is die voorsiening van hulp aan huishoudings wat deur kinders gelei word. Die hoofde van hierdie huishoudings kan nie vir kindertoelaes aansoek doen nie, omdat slegs persone in besit van identiteitsdokumente vir kindertoelaes mag aansoek doen. Kragtens die Identifikasie Wet (South Africa, 1997a) mag slegs persone van sestien jaar en ouer vir identiteitsdokumente aansoek doen. Die kinderhuishoudingshoofde is in baie gevalle te jonk om vir hierdie dokumente aansoek te doen. In die lig van die heersende MIV- en VIGS-epidemie en die groot aantal huishoudings wat deur kinders gelei word, behoort hierdie saak verdere aandag te geniet (vgl. Georgala, 1999:22).

Die ondertekening van verskillende konvensies met betrekking tot kinderarbeid deur die regering, is 'n positiewe stap met die oog op die bekamping van kinderarbeid, aangesien dit die owerheid verbind om daarteen op te tree. Wetgewing wat aangeneem is en wat kin- 
ders onder die ouderdom van vyftien (die ouderdom tot wanneer alle Suid-Afrikaanse kinders skoolpligtig is) verbied om te werk, is in die algemeen positief. ' $n$ Tekortkoming in die wetgewing is dat dit geen ruimte laat vir kinders om in gekontroleerde omstandighede werk te verrig wat op vaardigheidsontwikkeling gerig is, of om families in nood te help nie. In 'n land soos Suid-Afrika, waar daar 'n groot gebrek aan vaardighede is, behoort daaroor besin te word of kinders onder die ouderdom van vyftien nie in sekere omstandighede toegelaat behoort te word om te werk nie. Die doel moet wees om hulle voor te berei en op te lei vir 'n sinvolle beroep. Hierdie saak het sterk onder die soeklig gekom na aanleiding van die eerste hofsaak waarin werkgewers skuldig bevind is aan die verskaffing van werk aan kinders. Die eienaars van 'n plaas is daaraan skuldig bevind dat hulle kinders tydens 'n skoolvakansie in diens geneem het (op versoek van die kinders se ouers), om vrugte te pluk en op te tel. Die werk wat die kinders verrig het, het nie inbreuk op hulle skoolonderrig gemaak nie en dit het hulle ook nie fisies, geestelik of andersins benadeel nie (Anon., 2002:10).

Botha (1992:22) het reeds in 1992 voorgestel dat kinders toegelaat behoort te word om onder sekere voorwaardes te werk. Volgens die voorstel moet die werk wat kinders verrig, nie tot die ontwrigting van hulle skoolonderrig lei nie, hulle nie fisies of geestelik benadeel, of tot nadeel van volwasse werkers wees nie. Die vergoeding wat hulle ontvang moet ook billik (markverwant) wees, sodat dit nie werksgeleenthede van volwasse werkers in die gevaar stel nie. Waar kinderarbeid in gekontroleerde toestande verrig word, kan dit bydra tot die ontwikkeling van 'n gesonde werksetiek, die aanleer van vaardighede en 'n kind in staat stel om sakgeld te verdien. Sulke kinderarbeid is in ooreenstemming met die Internasionale Arbeidsorganisasie (ILO, 2002:9) se siening dat kinders betaalde of onbetaalde werk kan verrig wat by hulle ouderdom of vlak van ontwikkeling pas. Sulke werk leer hulle 'n sin vir verantwoordelikheid, sekere vaardighede en dra by tot hulle ouers en hulle eie inkomste en welstand. Dit lewer ook 'n bydrae tot die land se ekonomie. Gesien teen die agtergrond van die huidige Suid-Afrikaanse arbeidsituasie verdien Botha se voorstelle verdere ondersoek, met die oog daarop om kinders die geleentheid te gee om aan die Bybelse arbeidsopdrag gehoorsaam te wees, sonder dat hulle benadeel of uitgebuit word.

Omdat kinderarbeid in Suid-Afrika in verreweg die meeste gevalle uit noodweer gedoen word, behoort hierdie kinders (en hulle families) gehelp te word, sodat hulle hulself behoorlik kan voorberei om 
eendag hulle vermoëns na behore te gebruik. In hierdie opsig rus daar 'n groot verantwoordelikheid op gelowiges om hulle medegelowiges in nood by te staan (vgl. Hand. 2:43-47; 4:32-37) en die geleentheid vir kinders te skep om hulself te bekwaam om as toegeruste werkers oor God se skepping te heers.

Gelowige werkers het 'n besondere verantwoordelikheid om kinders toe te rus vir die arbeidsmark, terwyl hulle teen uitbuiting beskerm word. Kinders kom van God en is vir Hom belangrik (vgl. Mark. 5:2143; 10:13-16). Hoewel kinderarbeid en die gepaardgaande probleme waarskynlik nog 'n geruime tyd in Suid-Afrika hoogty gaan vier, kan dit nie sonder meer aanvaar word nie. Gelowiges behoort 'n voorbeeld te stel in die opvoeding en beskerming van kinders, sodat dit vir hulle kinders moontlik is om 'n lewe te lei waarin hulle nie blootgestel word om ter wille van oorlewing werke te doen wat eie is aan die sondige natuur (bv. onsedelikheid, onreinheid en losbandigheid) nie. Onder veilige en beskermde omstandighede is dit vir kinders baie makliker om die vrug van die Gees (bv. liefde, vreugde en vrede) te dra.

\section{Slot}

Kinderarbeid in Suid-Afrika is nie so ' $\mathrm{n}$ ernstige probleem soos in sommige ander ontwikkelende lande nie. Tog is daar ' $n$ beduidende aantal kinders in die land wat werk doen wat hulle menswaardigheid aantas. Kinderarbeid is hoofsaaklik die gevolg van die sosio-ekonomiese omstandighede waarin kinders grootword. Die vermindering van kinderarbeid in die toekoms sal direk daarvan afhang of die sosio-ekonomiese omstandighede in die land verbeter.

Vanuit 'n teologies-etiese perspektief behoort kinders opgevoed en opgelei te word om hulle vermoëns so ver as moontlik te ontwikkel, sodat hulle as volwassenes so goed moontlik aan die Bybelse arbeidsopdrag kan voldoen. Kinders kan slegs behoorlik opgelei en opgevoed word wanneer hulle genoeg tyd en geleenthede daarvoor het. Kinders behoort onder gekontroleerde omstandighede ekonomiese aktiwiteite te kan verrig - aktiwiteite wat hulle voorberei om as volwassenes volwaardig aan die arbeidsmark deel te neem. Sulke ekonomiese aktiwiteite behoort by hulle ouderdom te pas en nie hulle welstand, opvoeding, fisiese of geestelike gesondheid of geestelike, morele en sosiale ontwikkeling te benadeel nie. Hulle behoort ook nie in mededinging te wees met volwasse werkers wat ekonomies afhanklik van die werk is nie. 
Kinderarbeid in Suid-Afrika veroorsaak dat 'n beduidende aantal kinders nie menswaardig behandel word nie. Dit is 'n probleem waaraan verskillende rolspelers dringend aandag behoort te skenk.

\section{Geraadpleegde bronne}

AGRELL, G. 1976. Work, toil and sustenance. Verbum: Ohlssons.

ANON. 1997. Child abuse and the impact of poverty. Agenda, 33:43-48.

ANON. 2000a. Mother city "hosts regular child-sex tours". The Star: 1, 24 Aug.

ANON. 2000b. Children of Africa still under labour yoke. The Star: 13, 9 Nov.

ANON. 2002. Kinderarbeid. Beeld: 10, 7 Feb.

AUERBACH, L. 1944. The Babylonian Talmud in selection. New York: Philosophical Library.

BHENGU, C. 2000a. Child labour shame. Sowetan: 1, 17 Apr.

BHENGU, C. 2000b. Child labour still rife in SA. Sowetan: 11, 22 Mar.

BHENGU, C. 2000c. No immediate respite for child labourers. Sowetan: 13, 30 Mar.

BHENGU, C. 2001. I'm tired of this life, says sex worker. Sowetan: 1, 28 Jun.

BIENERT, W. 1956. Die Arbeit nach der Lehre der Bibel: ein Beitrag zur evangelischen Sozialethik. Stuttgart: Evangelisches Verlagswerk.

BOTHA, A. 1992. SALU wil kinderwerk gewettig kry. Landbouweekblad, 22.

DACHI, H.A. \& GARRET, R.M. 2003. Child labour and its impact on children's access to and participation in primary education: a case study from Tanzania. http://www.dfid.gov.uk/pubs/files/childlabouranditsimpacted paper48.pdf Date of access: 2 Nov. 2007.

EDERSHEIM, A. 1988. Sketches of Jewish social life in the days of Christ. Grand Rapids: Edersheim.

FYFE, A. 2007. The worldwide movement against child labour: progress and future directions. http://www.ilo.org/ipecinfo/product/viewProduct.do? productld=5168 Date of access: 2 Nov. 2007.

GALLI, R. 2001. The economic impact of child labour. Geneva: International Institute for Labour Studies. http://www.ilo.org/public/english/bureau/inst/ download/dp12801.pdf Date of access: 2 Nov. 2007.

GEORGALA, I. 1999. Staat met hande in hare oor vigs se gevolge. Beeld: 22 , 1 Des.

GOSLINGA, C.J. 1959. Samuël. DI. 1. Kampen: Kok. (Korte verklaring der Heilige Schrift.)

hAGEMANN, F., DIALLO, Y., ETIENNE, A. \& MEHRAN, F. 2006. Global child labour trends: 2000 to 2004 . http://www.ilo.org/dyn/declaris/ DECLARATIONWEB.DOWNLOAD_BLOB?Var_DocumentID=6233 Date of access: 2 Nov. 2007.

ILO

See INTERNATIONAL LABOUR ORGANISATION

INTERNATIONAL LABOUR ORGANISATION. 1973. C 138 Minimum Age Convention. http://www.ilolex.ilo.ch:1567/cgi-lex/convde.pl?c138 Date of access: 13 Aug. 2001.

INTERNATIONAL LABOUR ORGANISATION. 1999. C 182 Worst Forms of Child Labour Convention. http://www.ilolex.ilo.ch.1567/scripts/convde. pl?c182 Date of access: 1 Aug. 2001. 
INTERNATIONAL LABOUR ORGANISATION. 2002. A future without child labour. http://www.ilo.org/wcmsp5/groups/public/---ed_norm/---declaration/ documents/publication/kd00130.pdf Date of access: 3 Nov. 2007.

JOHANNES PAULUS II kyk JOHN PAUL II

JOHN PAUL II. 1981. Laborem exercens. http://www.newadvent.org/ docs/jp021e.htm Date of access: 16 Oct. 2003.

KAISER, W.C. 1991. Toward Old Testament ethics. Grand Rapids: Zondervan.

KOOLE, J.L. 1964. De tien geboden. Baarn: Bosch \& Keuning.

LABUSCHAGNE, J.M.T. 1994. Opmerkinge oor die posisie van die kind in die inheemse reg. De jure, 27:341-350.

MABASA, T. 2003. Child labour farmer is fined R12 000. The Citizen: 4, 5 Nov.

MDLADLANA, M.M.S. 2002. Speech by the honorable Minister of Labour, Mr M.M.S. Mdladlana at the launch of the International Labour Organisation's Third Global Report on a future without child labour. http://www.polity. org.za/govdocs/ speeches/2002/sp0506.html Date of access: 1 Jun. 2002.

NORVAL, E.J.G. 1966. Arbeid: prinsipiële ondersoek van arbeid met 'n kritiese toespitsing op enkele aktuele hoofprobleme van die arbeidsetiek. Potchefstroom: PU vir CHO. (Ph.D.-proefskrif.)

ORGANISASIE VAN AFRIKA EENHEID kyk ORGANISATION OF AFRICAN UNITY

ORGANISATION OF AFRICAN UNITY. 1990. African Charter on the Rights and Welfare of the Child. http://www.africaninstitute.org/html/african_ charter_on_the_rights.html Date of access: 1 Jun. 2002.

ORKIN, F.M. 2000. Child labour in South Africa: tables. http://www.datafirst. uct.ac.za/resource/young/syp_tables.pdf Date of access: 21 Nov. 2007.

PRINCE, L. \& ARENDS, N. 2002. Plaas beboet in 1ste kinderarbeidsaak. Beeld: 2, 6 Feb.

RADEBE, H. 2001. Blitz on illegals working on farms. The Citizen: 4, 20 Dec.

SKWEYIYA, Z. 2007. SA: Skweyiya: providing services to orphans and vulnerable children progress. http://www.polity.org.za/article.php?a_ id=120815 Date of access: 2 Nov. 2007.

SMITH, E.M. 1995. Children. (In Atkinson, D.J. \& Field, D.H., eds. New dictionary of Christian ethics and pastoral theology. Leicester: InterVarsity. p. 225-226.)

SOUTH AFRICA. 1996a. Constitution of the Republic of South Africa Act, No. 108 of 1996. http://www.polity.org.za/govdocs/constitution/saconst.html Date of access: 13 Nov. 2001.

SOUTH AFRICA. 1996b. South African Schools Act, No. 84 of 1996. http://www.polity.org.za/html/govdocs/legislation/1996/act96-084.html Date of access: 26 Aug. 2004.

SOUTH AFRICA. 1997a. Identification Act, No. 68 of 1997. http://www.info. gov.za/gazette/acts/1997/a68-97.pdf Date of access: 2 Nov. 2007.

SOUTH AFRICA. 1997b. Basic Conditions of Employment Act, No. 75 of 1997. http://www.polity.org.za/govdocs/legislation/1997/act75.pdf Date of access: 13 Aug. 2001.

SOUTH AFRICA. 2005. Children's Act, No. 38 of 2005. http://llnw. creamermedia.co.za/articles/attachments/02888_childrensact38.pdf Date of access: 2 Nov. 2007. 
SOUTH AFRICA. Department of Labour. 2003. The National Child Labour Action Programme for South Africa: final draft for consideration by government departments and other stakeholders. http://www.labour. gov.za/useful_docs/doc_display.jsp?id=9503 Date of access: 2 Nov. 2007.

SOUTH AFRICA. DL

UNICEF see SOUTH AFRICA. Department of labour.

see UNITED NATIONS CHILDEN'S FUND

UNITED NATIONS. 1989. Convention on the Rights of the Child. http://www.unhchr.ch/html/menu3/b/k2crc.htm Date of access: 11 Jun. 2002.

UNITED NATIONS CHILDREN'S FUND. 2005. Excluded and invisible. http://www.unicef.org/publications/files/SOWC_2006_English_Report_rev

(1).pdf Date of access: 2 Nov. 2007.

VAN DIJK, P. 1985. Op de grens van twee werelden: een onderzoek naar het ethische denken van de natuurwetenschapper C.J. Dippel. 's-Gravenhage: Boekencentrum.

VORSTER, J.M. 2007. Christian attitude in the South African liberal democracy. Potchefstroom: Potchefstroom Theological Publications.

WALTON, J.H. 2001. Genesis. Grand Rapids: Zondervan. (The NIV application commentary.)

WEISSBRODT, D. \& ANTI-SLAVERY INTERNATIONAL. 2002. Abolishing slavery and its contemporary forms. New York: United Nations. http://www.unhchr.ch/pdf/slavery.pdf Date of access: 21 Nov. 2007.

WESSEL, W.W. 1984. Matthew, Mark, Luke. Grand Rapids: Zondervan. (The expositor's Bible commentary with the New International Version.)

\section{Kernbegrippe:}

arbeid

armoede

kinderarbeid

werk

Key concepts:

child labour

labour

poverty

work 
